\title{
Lentibacillus halophilus sp. nov., from fish sauce in Thailand
}

Correspondence

Somboon Tanasupawat

Somboon.T@chula.ac.th

\author{
Somboon Tanasupawat, ${ }^{1}$ Amnat Pakdeeto, ${ }^{1}$ Sirilak Namwong, ${ }^{1}$ \\ Chitti Thawai, ${ }^{1}$ Takuji Kudo ${ }^{2}$ and Takashi Itoh ${ }^{2}$ \\ ${ }^{1}$ Department of Microbiology, Faculty of Pharmaceutical Sciences, Chulalongkorn University, \\ 254 Phayathai Road, Wangmai, Pathumwan, Bangkok 10330, Thailand \\ 2Japan Collection of Microorganisms, RIKEN BioResource Center, 2-1 Hirosawa, Wako-shi, \\ Saitama 351-0198, Japan
}

Fifteen strains of extremely halophilic bacteria were isolated from fish sauce (nam-pla) collected in Thailand at various stages of the fish-fermentation process. The isolates were strictly aerobic, spore-forming, Gram-positive rods. They grew optimally in the presence of $20-26 \% \mathrm{NaCl}$. The cell-wall peptidoglycan contained meso-diaminopimelic acid. The predominant menaquinone was MK-7. The major cellular fatty acids were anteiso- $\mathrm{C}_{15: 0}$ and anteiso- $\mathrm{C}_{17: 0}$. Polar lipid analysis revealed the presence of phosphatidylglycerol, diphosphatidylglycerol and two unidentified glycolipids. The DNA G + C content was $42 \cdot 1-43 \cdot 1$ mol\%. On the basis of the $16 \mathrm{~S}$ rRNA gene sequence, a representative strain, $\mathrm{PS} 11-2^{\top}$, was found to be closely related to Lentibacillus juripiscarius JCM $12147^{\top}$ (97.3\% similarity). The 15 strains were included in the same species on the basis that the levels of DNA-DNA relatedness with strain PS11-2 ${ }^{\top}$ were greater than $70 \%$. They could be distinguished from $L$. juripiscarius and other Lentibacillus species on the basis of several phenotypic characteristics and low levels of DNA-DNA relatedness ( $\leqslant 19 \cdot 4 \%)$.

Therefore, the strains represent a novel species of the genus Lentibacillus, for which the name Lentibacillus halophilus sp. nov. is proposed. The type strain is PS11-2 ${ }^{\top}\left(=\mathrm{JCM} 12149^{\top}=\mathrm{TISTR}^{\mathrm{N}}\right.$ $1549^{\top}=$ PCU $240^{\top}$ ).
Moderately halophilic, endospore-forming, rod-shaped bacteria are widely distributed in environments containing high $\mathrm{NaCl}$ concentrations, such as saline lakes and fish sauce. They are a diverse group of bacteria belonging to the genera Bacillus, Halobacillus, Virgibacillus, Filobacillus, Oceanobacillus, Lentibacillus and Pontibacillus (Ventosa et al., 1989; Spring et al., 1996; Heydrickx et al., 1998; Arahal et al., 2000; Schlesner et al., 2001; Lu et al., 2001; Heyrman et al., 2003; Yoon et al., 2002, 2004; Lim et al., 2005a). The genus Lentibacillus, which forms a phylogenetically coherent group, currently comprises four species: Lentibacillus salicampi, L. juripiscarius, L. salarius and $L$. lacisalsi (Yoon et al., 2002; Namwong et al., 2005; Jeon et al., 2005; Lim et al., 2005b). In this paper, we report the isolation and identification of some novel extremely halophilic strains representing a novel Lentibacillus species.

The GenBank/EMBL/DDBJ accession number for the $16 \mathrm{~S}$ rRNA gene sequence of strain PS11-2 ${ }^{\top}$ is $A B 191345$.

A scanning electron micrograph of sporulating cells of strain PS11-2 ${ }^{\top}$, a thin-layer chromatogram of polar lipids and details of the cellular fatty acids and levels of DNA-DNA relatedness of the novel strains and related taxa are available as supplementary material in IJSEM Online.
Fish-sauce samples were collected from fish-sauce factories in Thailand during the early, middle and late stages of the fermentation process. Halophilic bacteria were isolated from the samples by using the spread plate technique on agar plates of JCM medium no. 168 (containing, $1^{-1}, 200 \mathrm{~g}$ $\mathrm{NaCl}, 5 \mathrm{~g}$ Casamino acids, $5 \mathrm{~g}$ yeast extract, $1 \mathrm{~g}$ glutamic acid, $2 \mathrm{~g} \mathrm{KCl}, 3 \mathrm{~g}$ trisodium citrate, $20 \mathrm{~g} \mathrm{MgSO}_{4} .7 \mathrm{H}_{2} \mathrm{O}$, $36 \mathrm{mg} \mathrm{FeCl} 2.4 \mathrm{H}_{2} \mathrm{O}, 0.36 \mathrm{mg} \mathrm{MnCl}_{2} .4 \mathrm{H}_{2} \mathrm{O}$ and $20 \mathrm{~g}$ agar; $\mathrm{pH} 7 \cdot 2$ ] with incubation at $37^{\circ} \mathrm{C}$ for 7 days. Liquid cultures were cultivated in Erlenmeyer flasks containing the same medium without agar and were incubated on a rotary shaker. All media contained $20 \%(\mathrm{w} / \mathrm{v}) \mathrm{NaCl}$, except those used to investigate $\mathrm{NaCl}$ tolerance. Cell shape, cell size and cell arrangement were examined on JCM medium no. 168 agar at $37^{\circ} \mathrm{C}$ for 5 days. The Hucker-Conn modification was used for Gram staining (Hucker \& Conn, 1923). Spore formation was examined on Gram-stained specimens. Critical-point-dried cells were observed under a scanning electron microscope. Flagella were examined as described by Forbes (1981) and observed by transmission electron microscopy. Catalase activity, oxidase activity and the hydrolysis of aesculin were investigated as described by Barrow \& Feltham (1993), while urease activity and the hydrolysis of gelatin, casein, starch, Tween 80, tyrosine, 
phenylalanine, xanthine and hypoxanthine were tested as described by Namwong et al. (2005). Arginine hydrolysis was investigated by using the medium reported by Thornley (1960). Acid production from carbohydrate was determined in the medium described by Leifson (1963), supplemented with $20 \% \mathrm{NaCl}$. Growth under anaerobic conditions on agar plates with or without $\mathrm{KNO}_{3}(1 \%$, w/v) was performed in a Gaspak (BBL) anaerobic jar. Growth at various temperatures $\left(10-50^{\circ} \mathrm{C}\right), \mathrm{pH}$ values $(5,6,7,7 \cdot 5,8$ and 9$)$ and $\mathrm{NaCl}$ concentrations $(0-30 \%, \mathrm{w} / \mathrm{v})$ was tested by using JCM medium no. 168 as a basal medium (Namwong et al., 2005).

The diaminopimelic acid in the peptidoglycan and the menaquinone composition were determined as described previously (Komagata \& Suzuki, 1987). Polar lipids were investigated according to the methods of Minnikin et al. (1984) and Albert et al. (2005). A loop of cell mass was used for the extraction and quantitative analysis of the cellular fatty acids by means of the Microbial Identification System (MIDI) (Sasser, 1990; Kämpfer \& Kroppenstedt, 1996).

DNA was isolated from cells grown in JCM medium no. 168 broth and purified according to the method of Saito \&
Miura (1963). The DNA G $+\mathrm{C}$ content was determined by the method of Tamaoka \& Komagata (1984), using reversed-phase HPLC. DNA-DNA hybridization was conducted in microdilution-well plates, as reported by Ezaki et al. (1989), and was detected by using the colorimetric method described by Tanasupawat et al. (2000). The $16 \mathrm{~S}$ rRNA gene of the isolate was amplified, purified and sequenced as described previously (Seearunruangchai et al., 2004). The sequence determined (1410 bases) was aligned with selected sequences (obtained from the GenBank/ EMBL/DDBJ database) by using CLUSTAL $\mathrm{W}$, version 1.81 (Thompson et al., 1994). The alignment was manually edited to remove gaps and ambiguous nucleotides prior to the construction of the phylogenetic tree. The phylogenetic tree was constructed by using the neighbour-joining method (Saitou \& Nei, 1987) in MEGA, version 2.1 (Kumar et al., 2001). The confidence values of branches of the phylogenetic tree were determined using bootstrap analyses (Felsenstein, 1985) based on 1000 resamplings.

Fifteen aerobic, extremely halophilic bacteria were isolated from the fish-sauce samples, and were characterized according to their morphological, cultural, physiological and

Table 1. Differential characteristics of Lentibacillus species

Strains: 1, PS11-2 $2^{\mathrm{T}}$; 2, L. juripiscarius JCM $12147^{\mathrm{T}}$ (data from Namwong et al., 2005); 3, L. salarius KCTC 3911 ${ }^{\mathrm{T}}$ (Jeon et al., 2005); 4, L. salicampi JCM $11462^{\mathrm{T}}$ (Yoon et al., 2002; Namwong et al., 2005); 5, L. lacisalsi KCTC $3915^{\mathrm{T}}$ (Lim et al., 2005b). +, Positive; -, negative; W, weak; NA, no data available.

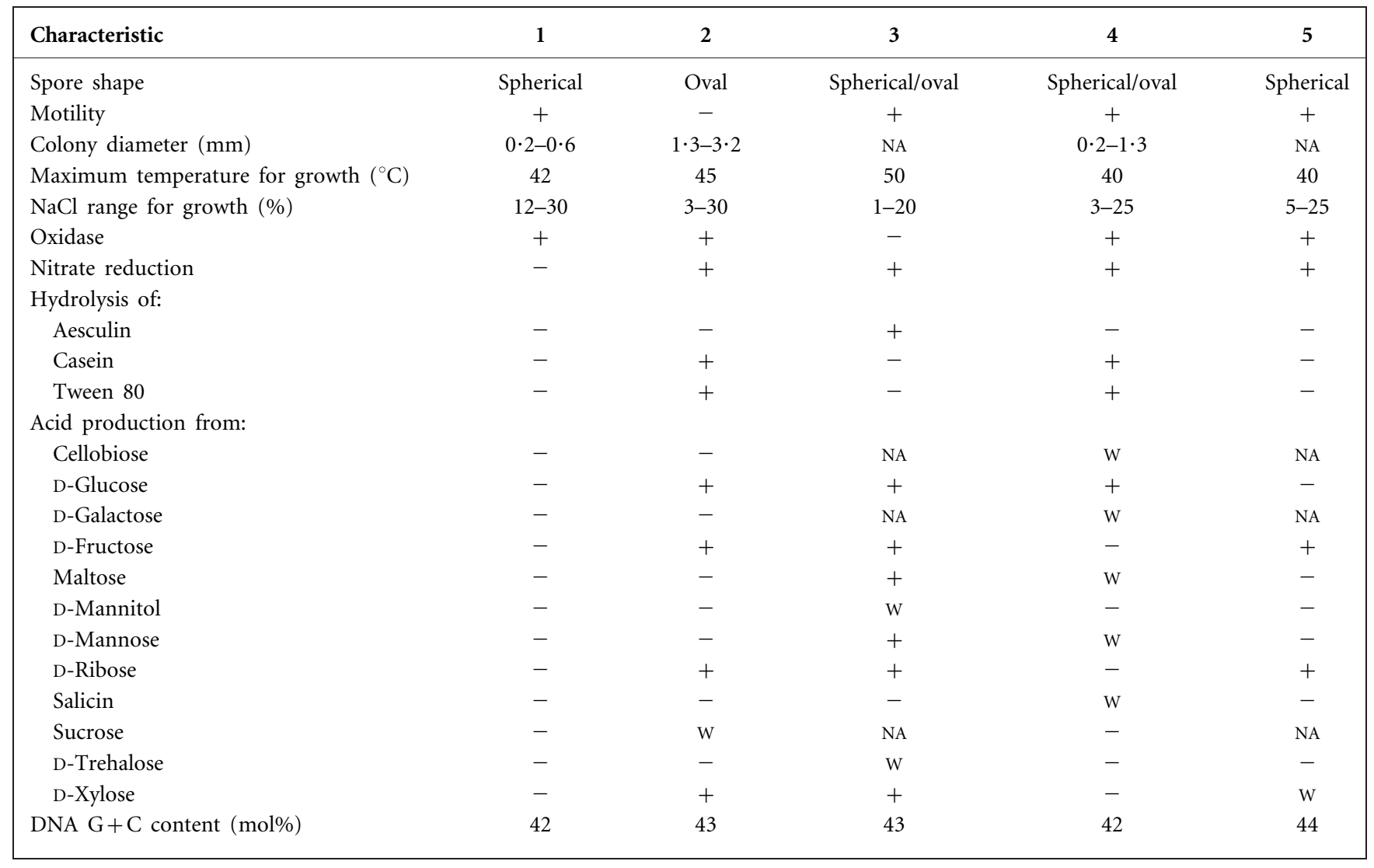


biochemical properties. The results are listed in the species description and Table 1. All 15 strains contained mesodiaminopimelic acid as the diagnostic diamino acid in the cell-wall peptidoglycan. The menaquinones, cellular fatty acids and polar lipids of four of these strains, namely PS11-2 ${ }^{\mathrm{T}}$, CB0-1, DS26-3 and DB9-1, were analysed. The four strains contained the following: MK-7 as a major menaquinone; anteiso- $\mathrm{C}_{15: 0}(58 \cdot 0-62 \cdot 7 \%)$, anteiso- $\mathrm{C}_{17: 0}$ $(24 \cdot 6-33 \cdot 8 \%), \mathrm{C}_{16: 0}(1 \cdot 7-3 \cdot 0 \%)$, iso- $\mathrm{C}_{15: 0}(2 \cdot 7-7 \cdot 8 \%)$ and iso- $\mathrm{C}_{16: 0}(1 \cdot 8-2 \cdot 3 \%)$ as the cellular fatty acids (see Supplementary Table S1 available in IJSEM Online); and phosphatidylglycerol, diphosphatidylglycerol and two unidentified glycolipids as major polar lipids (see Supplementary Fig. S1 available in IJSEM Online).

The DNA G $+\mathrm{C}$ content of the isolates (13 strains) ranged from $42 \cdot 1$ to $43 \cdot 1 \mathrm{~mol} \%$. In the neighbour-joining phylogenetic tree based on 16S rRNA gene sequences, strain PS1 $1-2^{\mathrm{T}}$ was positioned in a monophyletic cluster consisting of the members of the genus Lentibacillus (Fig. 1). The same topology was obtained by applying the maximumparsimony method (result not shown). The 16S rRNA gene sequence similarity values between $\mathrm{PS} 11-2^{\mathrm{T}}$ and $L$. juripiscarius JCM $12147^{\mathrm{T}}$, L. salarius KCTC $3911^{\mathrm{T}}$, L. lacisalsi KCTC $3915^{\mathrm{T}}$ and L. salicampi JCM $11462^{\mathrm{T}}$ were $97 \cdot 3,95 \cdot 5,95 \cdot 4$ and $95 \cdot 3 \%$, respectively. Furthermore, strain PS11-2 ${ }^{\mathrm{T}}$ showed $93 \cdot 3-94 \cdot 2 \% \quad 16 \mathrm{~S}$ rRNA gene sequence similarity to members of the genus Virgibacillus. Hybridization studies revealed high levels of DNA-DNA relatedness between PS1 $1-2^{\mathrm{T}}$ and PB7-3 and to the other isolates (>70\%), but only low levels with respect to $L$. salicampi JCM $11462^{\mathrm{T}}(4 \cdot 9-19 \cdot 4 \%)$ and L. juripiscarius
JCM $12147^{\mathrm{T}}(17 \cdot 0-17 \cdot 1 \%)$, as shown in Supplementary Table S2 (available in IJSEM Online).

The 16S rRNA gene sequence-based phylogenetic analysis clearly indicated that representative strain PS1 $1-2^{\mathrm{T}}$ belongs to the genus Lentibacillus. The chemotaxonomic properties (i.e. diamino acid content in the peptidoglycan, menaquinone content, the polar lipids and the cellular fatty acid profiles) of the isolates were in accordance with those of the genus Lentibacillus (Yoon et al., 2002; Namwong et al., 2005; Jeon et al., 2005; Lim et al., 2005b). The fatty acid profiles of the four strains examined were qualitatively similar to those of other Lentibacillus species, although the levels of iso- $\mathrm{C}_{14: 0}$ and iso- $\mathrm{C}_{16: 0}$ were significantly lower than those of the other Lentibacillus species reported $\left(\leqslant 0 \cdot 7 \%\right.$ iso- $\mathrm{C}_{14: 0}$ and $1 \cdot 8-2 \cdot 3 \%$ iso- $\mathrm{C}_{16: 0}$ for the isolates; $5 \cdot 7-13.9 \%$ iso- $\mathrm{C}_{14: 0}$ and $16 \cdot 3-26 \cdot 5 \%$ iso- $C_{16: 0}$ for Lentibacillus species). When the cellular fatty acid profile of $L$. juripiscarius JCM $12147^{\mathrm{T}}$ grown on JCM medium no. 168 (containing $20 \% \mathrm{NaCl}$ ) was compared with the profile from cells grown on the Lentibacillus medium (JCM medium no. 377, containing $10 \%$ $\mathrm{NaCl}$ ), the levels of iso- $\mathrm{C}_{14: 0}$ and iso- $\mathrm{C}_{16: 0}$ were significantly lower $(2 \cdot 1$ and $6 \cdot 3 \%$, respectively: see Supplementary Table S1 in IJSEM Online). Thus, the levels of iso- $\mathrm{C}_{14: 0}$ and iso- $\mathrm{C}_{16: 0}$ were affected by $\mathrm{NaCl}$ concentration during growth. The morphological, cultural, physiological and biochemical characteristics that differentiate the isolates from Lentibacillus species are shown in Table 1. It is noteworthy that all of the isolates are extreme halophiles requiring at least $12 \% \mathrm{NaCl}$ for growth. In addition, the isolates do not reduce nitrate and do not produce acid from sugars, unlike Lentibacillus species. The 16S rRNA gene sequence of PS11-2 ${ }^{\mathrm{T}}$ shows a relatively

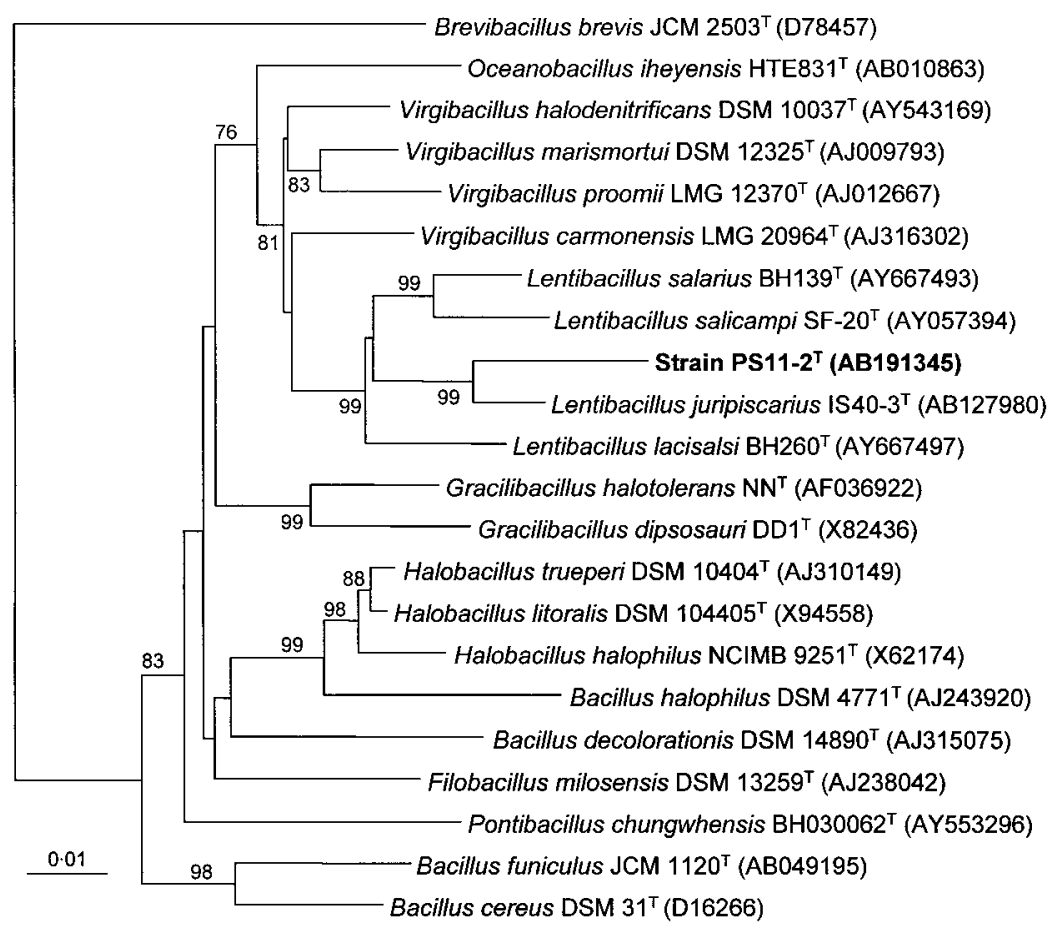

Fig. 1. Phylogenetic tree, based on $16 \mathrm{~S}$ rRNA gene sequences, showing the relationships between strain $\mathrm{PS} 11-2^{\mathrm{T}}$ and related bacterial species. The branching pattern was generated by the neighbour-joining method. Bootstrap percentages above $75 \%$, based on 1000 replications, are shown at the nodes. Bar, 1 substitution per 100 nucleotide positions. 
high level of similarity to that of the type strain of $L$. juripiscarius $(97 \cdot 3 \%)$. However, the low levels of DNA-DNA relatedness $(\leqslant 19 \cdot 4 \%)$ demonstrate that the novel strains do not belong to the species L. juripiscarius. On the other hand, inclusion of the 15 strains in the same species is supported by the fact that they share the same phenotypic properties and demonstrate high levels of DNA-DNA relatedness to each other (>70\%) (Wayne et al., 1987). Therefore, these 15 isolates represent a novel species in the genus Lentibacillus, for which we propose the name Lentibacillus halophilus sp. nov. The type strain is PS11-2 ${ }^{\mathrm{T}}\left(=\mathrm{JCM} 12149^{\mathrm{T}}=\right.$ TISTR $1549^{\mathrm{T}}=$ PCU $240^{\mathrm{T}}$ ).

\section{Description of Lentibacillus halophilus sp. nov.}

Lentibacillus halophilus (ha.lo' phi.lus. Gr. n. hals, halos salt; Gr. adj. philos loving; N.L. masc. adj. halophilus salt-loving).

Cells are Gram-positive, aerobic, motile rods and are mostly $0 \cdot 4-0 \cdot 6 \mu \mathrm{m}$ wide and $1 \cdot 0-3 \cdot 0 \mu \mathrm{m}$ long. Longer cells (up to $6 \mu \mathrm{m}$ ) or short filaments are observed. Spherical endospores are formed terminally in swollen sporangia (see Supplementary Fig. S2 available in IJSEM Online). Colonies are white to cream, low-convex or raised, smooth and circular $(0 \cdot 1-0 \cdot 8 \mathrm{~mm}$ in diameter). Catalase- and oxidase-positive. Urease-negative. Growth occurs between $15^{\circ} \mathrm{C}$ (weakly) and $42^{\circ} \mathrm{C}$ (optimum, $30-37^{\circ} \mathrm{C}$ ) but not at 10,45 or $50^{\circ} \mathrm{C}$. Growth is observed between pH 6 and 8 (optimum, $\mathrm{pH} 7 \cdot 0-7 \cdot 5$ ) but not at $\mathrm{pH} 5$ or 9 . Extremely halophilic, growing in the presence of $12-30 \%(\mathrm{w} / \mathrm{v}) \mathrm{NaCl}$ but not at or below $10 \%(\mathrm{w} / \mathrm{v}) \mathrm{NaCl}$ (optimum, $20-26 \% \mathrm{NaCl}$, w/v). Anaerobic growth is not observed in the presence of $1 \%$ $\mathrm{KNO}_{3}$ (w/v) or in other media. Aesculin, arginine, casein, gelatin, Tween 80 , tyrosine, starch, phenylalanine, xanthine and hypoxanthine are not hydrolysed. Acid is not produced from D-glucose, glycerol, D-ribose, D-xylose, L-arabinose, cellobiose, D-fructose, D-galactose, lactose, maltose, Dmannitol, D-mannose, D-melibiose, D-melezitose, myoinositol, raffinose, L-rhamnose, salicin, sorbitol, sucrose or D-trehalose. Contains meso-diaminopimelic acid as the diagnostic diamino acid in the cell-wall peptidoglycan. MK7 is the major menaquinone. The fatty acid profile consists of anteiso- $\mathrm{C}_{15: 0}(58 \cdot 0-62 \cdot 7 \%)$, anteiso- $\mathrm{C}_{17: 0}(24 \cdot 6-33 \cdot 8 \%)$, iso- $\mathrm{C}_{15: 0} \quad(2 \cdot 4-7 \cdot 8 \%), \quad \mathrm{C}_{16: 0} \quad(1 \cdot 7-3 \cdot 0 \%), \quad$ iso- $\mathrm{C}_{16: 0}$ $(1 \cdot 8-2 \cdot 3 \%)$, iso- $\mathrm{C}_{17: 0}(0 \cdot 5-1 \cdot 4 \%), \mathrm{C}_{14: 0}(0-0 \cdot 9 \%)$, iso$\mathrm{C}_{14: 0}(0-0 \cdot 7 \%), \mathrm{C}_{15: 0}(0-0 \cdot 6 \%)$ and $\mathrm{C}_{12: 0}(0-0 \cdot 5 \%)$. Phosphatidylglycerol, diphosphatidylglycerol and two unidentified glycolipids are predominant in the polar lipid profile. The DNA G $+\mathrm{C}$ content is $42 \cdot 1-43 \cdot 1 \mathrm{~mol} \%$ (type strain, $42 \cdot 4 \mathrm{~mol} \%)$.

The type strain, PS11-2 $2^{\mathrm{T}}\left(=\mathrm{JCM} 12149^{\mathrm{T}}=\right.$ TISTR $1549^{\mathrm{T}}=$ PCU $240^{\mathrm{T}}$ ), was isolated from a fish-sauce fermentation in Thailand.

\section{Acknowledgements}

We are very grateful to Sindhu Samuth Fish Sauce Factory (Squid Brand) Ltd (Samutprakarn), Thai Fish Sauce Factory (Squid Brand)
Co., Ltd (Samutsongkram) and Pichai Fish Sauce Co., Ltd (Chonburi) for providing the samples. This study was supported, in part, by Ratchadapiseksomphot Research Grant, Chulalongkorn University (2002).

\section{References}

Albert, R. A., Archambault, J., Rosselló-Mora, R., Tindall, B. J. \& Matheny, M. (2005). Bacillus acidicola sp. nov., a novel mesophilic, acidophilic species isolated from acidic Sphagnum peat bogs in Wisconsin. Int J Syst Evol Microbiol 55, 2125-2130.

Arahal, D. R., Marquez, M. C., Volcani, B. E., Schleifer, K. H. \& Ventosa, A. (2000). Reclassification of Bacillus marismortui as Salibacillus marismortui comb. nov. Int J Syst Evol Microbiol 50, 1501-1503.

Barrow, G. I. \& Feltham, R. K. A. (1993). Cowan and Steel's Manual for the Identification of Medical Bacteria, 3rd edn. Cambridge: Cambridge University Press.

Ezaki, T., Hashimoto, Y. \& Yabuuchi, E. (1989). Fluorometric deoxyribonucleic acid-deoxyribonucleic acid hybridization in microdilution wells as an alternative to membrane filter hybridization in which radioisotopes are used to determine genetic relatedness among bacterial strains. Int J Syst Bacteriol 39, 224-229.

Felsenstein, J. (1985). Confidence limits on phylogenies: an approach using the bootstrap. Evolution 39, 783-791.

Forbes, L. (1981). Rapid flagella stain. J Clin Microbiol 13, 807-809. Heydrickx, M., Lebbe, L., Kersters, K., De Vos, P., Forsyth, G. \& Logan, N. A. (1998). Virgibacillus: a new genus to accommodate Bacillus panthothenticus (Proom and Knight 1995). Emended description of Virgibacillus panthothenticus. Int J Syst Bacteriol 48, 99-106.

Heyrman, J., Logan, N. A., Busse, H.-J., Balcaen, A., Lebbe, L., Rodriguez-Diaz, M., Swings, J. \& De Vos, P. (2003). Virgibacillus carmonensis sp. nov., Virgibacillus necropolis sp. nov. and Virgibacillus picturae sp. nov., three novel species isolated from deteriorated mural paintings, transfer of the species of genus Salibacillus to Virgibacillus, as Virgibacillus marismortui comb. nov. and Virgibacillus salexigens comb. nov., and emended description of the genus Virgibacillus. Int J Syst Evol Microbiol 53, 501-511.

Hucker, G. J. \& Conn, H. J. (1923). Method of Gram staining. Tech Bull N Y St Agric Exp Stn 93, 3-37.

Jeon, C. O., Lim, J.-M., Lee, G. S., Lee, J.-M., Xu, L.-H., Jiang, C.-L. \& Kim, C.-J. (2005). Lentibacillus salarius sp. nov., isolated from saline sediment in China and emended description of genus Lentibacillus. Int J Syst Evol Microbiol 55, 1339-1343.

Kämpfer, P. \& Kroppenstedt, R. M. (1996). Numerical analysis of fatty acid patterns of coryneform bacteria and related taxa. Can J Microbiol 42, 989-1005.

Komagata, K. \& Suzuki, K. (1987). Lipid and cell-wall analysis in bacterial systematics. Methods Microbiol 19, 161-203.

Kumar, S., Tamura, K., Jakobson, I.-B. \& Nei, M. (2001). MEGA 2: molecular evolutionary genetics analysis software. Bioinformatics 17, 1244-1245.

Leifson, E. (1963). Determination of carbohydrate metabolism of marine bacteria. J Bacteriol 85, 1183-1184.

Lim, J.-M., Jeon, C. O., Song, S. M. \& Kim, C.-J. (2005a). Pontibacillus chungwhensis gen. nov., sp. nov., a moderately halophilic Grampositive bacterium from a solar saltern in Korea. Int J Syst Evol Microbiol 55, 165-170.

Lim, J.-M., Jeon, C. O., Song, S. M., Lee, J.-C., Ju, Y. J., Xu, L. H., Jiang, C.-L. \& Kim, C.-J. (2005b). Lentibacillus lacisalsi sp. nov., a 
moderately halophilic bacterium isolated from a saline lake in China. Int J Syst Evol Microbiol 55, 1805-1809.

Lu, J., Nogi, Y. \& Takami, H. (2001). Oceanobacillus iheyensis gen. nov., sp. nov., a deep-sea extremely halotolerant and alkaliphilic species isolated from a depth of $1050 \mathrm{~m}$ on the Iheya Ridge. FEMS Microbiol Lett 205, 291-297.

Minnikin, D. E., O’Donnell, A. G., Goodfellow, M., Alderson, G., Athalye, M., Schaal, A. \& Parlett, J. H. (1984). An integrated procedure for the extraction of bacterial isoprenoid quinones and polar lipids. J Microbiol Methods 2, 233-241.

Namwong, S., Tanasupawat, S., Smitinont, T., Visessanguan, W., Kudo, T. \& Itoh, T. (2005). Isolation of Lentibacillus salicampi strains and Lentibacillus juripiscarius sp. nov. from fish sauce in Thailand. Int J Syst Evol Microbiol 55, 315-320.

Saito, H. \& Miura, K. (1963). Preparation of transforming deoxyribonucleic acid by phenol treatment. Biochim Biophys Acta 72, 619-629.

Saitou, N. \& Nei, M. (1987). The neighbor-joining method: a new method for reconstructing phylogenetic trees. Mol Biol Evol 4 406-425.

Sasser, M. (1990). Identification of bacteria by gas chromatography of cellular fatty acids. MIDI Technical Note 101. Newark, DE: MIDI.

Schlesner, H., Lawson, P. A., Collins, M. D., Weiss, N., Wehmeyer, U., Volker, H. \& Thomm, M. (2001). Filobacillus milensis gen. nov., sp. nov., a new halophilic spore-forming bacterium with Orn-D-Glutype peptidoglycan. Int J Syst Evol Microbiol 51, 425-431.

Seearunruangchai, A., Tanasupawat, S., Keeratipibul, S., Thawai, C., Itoh, T. \& Yamada, Y. (2004). Identification of acetic acid bacteria isolated from fruits and related materials collected in Thailand. J Gen Appl Microbiol 50, 47-53.

Spring, S., Ludwig, W., Marquez, M. C., Ventosa, A. \& Schleifer, K.-H. (1996). Halobacillus gen. nov., with descriptions of Halobacillus litoralis sp. nov. and Halobacillus trueperi sp. nov., and transfer of Sporosarcina halophilia to Halobacillus halophilus comb. nov. Int J Syst Bacteriol 46, 492-496.

Tamaoka, J. S. \& Komagata, K. (1984). Determination of DNA base composition by reverse-phase high-performance liquid chromatography. FEMS Microbiol Lett 25, 125-128.

Tanasupawat, S., Shida, O., Okada, S. \& Komagata, K. (2000). Lactobacillus acidipiscis sp. nov. and Weissella thailandensis sp. nov., isolated from fermented fish in Thailand. Int J Syst Evol Microbiol 50, 1479-1485.

Thompson, J. D., Higgins, D. G. \& Gibson, T. J. (1994). CLUSTAL W: improving the sensitivity of progressive multiple sequence alignment through sequence weighting, position-specific gap penalties and weight matrix choice. Nucleic Acids Res 22, 4673-4680.

Thornley, M. J. (1960). The differentiation of Pseudomonas from other Gram-negative bacteria on the basis of arginine metabolism. J Appl Bacteriol 23, 37-52.

Ventosa, A., Garcia, M. T., Kamekura, M., Onishi, H. \& RuizBerraquero, M. (1989). Bacillus halophilus sp. nov., a moderately halophilic Bacillus species. Syst Appl Microbiol 12, 162-165.

Wayne, L. G., Brenner, D. J., Colwell, R. R. \& 9 other authors (1987). International Committee on Systematic Bacteriology. Report of the ad hoc committee on reconciliation of approaches to bacterial systematics. Int J Syst Bacteriol 37, 463-464.

Yoon, J.-H., Kang, K. H. \& Park, Y.-H. (2002). Lentibacillus salicampi gen. nov., sp. nov., a moderately halophilic bacterium isolated from a salt field in Korea. Int J Syst Evol Microbiol 52, 2043-2048.

Yoon, J.-H., Oh, T. K. \& Park, Y.-H. (2004). Transfer of Bacillus halodenitrificans Denariaz et al. 1989 to the genus Virgibacillus as Virgibacillus halodenitrificans comb. nov. Int J Syst Evol Microbiol 54, 2163-2167. 